\title{
US plan just a memory
}

\section{San Francisco}

THE demise last week of US Memories Inc., a unique and controversial semiconductor manufacturing joint venture, has ended a major attempt by US companies to combat Japanese domination of the critical memory chip arena. The question now is whether it was the last chance, but the venture's chief critic, T.J. Rodgers of Cypress Semiconductor Corporation, still proclaims that the US will "blow away" its Japanese rival early in the next century.

Disagreement centres on whether the combination of improvements in US manufacturing quality - up to now one of the major strengths of the Japanese competition - and the traditional US strength in pioneering new technologies will give the United States a chance to get back on top. Those who helped set up US Memories last June think it will not, and argue that America's only hope is a massive collaborative effort by a consortium of companies. The collaboration was established in the wake of a dramatic shortage of DRAM semiconductors which had caused prices to soar.

DRAMs, which are central to a variety of electronic products, were first developed in the United States by Intel Corporation. But since 1980 , the US market share has fallen from 60 per cent to about 15 per cent. Japanese companies now account for nearly 80 per cent of the $\$ 9,400$ million market, according to the consulting firm Dataquest.

American chipmakers claim that the Japanese forced them out of the business by dumping DRAMs at artificially low prices. To protect themselves against future shortages and the chance of unfair competition, American buyers wanted another US source. But given the extraordinarily high cost of getting into the business, an estimated $\$ 1,000$ million, they wanted to spread the risk. That provided the logic for the establishment of US Memories.

Backers of US Memories included several major semiconductor manufacturers: IBM, Hewlett-Packard, Intel, Digital Equipment Corporation, National Semiconductor, LSI Logic and Advanced Micro Devices. The original plan called for them, and the other supporters that were expected to jump on board, to put up at least half the $\$ 1,000$ million needed to establish the new venture as a manufacturer of 4-megabit DRAMs, the next generation of memory chips.

But last week, US Memories president Sanford Kane announced that the effort was dead long before it produced a single product. Several factors marred the effort. The new venture was in some ways similar to SEMATECH, a Texas-based consortium that receives government and industry funds for research and development into semiconductors, including DRAMS. But unlike SEMATECH, US Memories would have manufactured DRAMS and so may have violated antitrust law.

From the beginning, critics let it be known that there might be an anti-trust battle. But it was lack of finance that really proved US Memories' undoing. With the DRAM shortage ending, many potential supporters of the venture felt US Memories was no longer vital. At the end of the day, not enough backers were left to make the venture possible.

The demise of US Memories was also a personal victory for Rodgers, a leading critic of the venture and chief executive officer of a highly successful semiconductor company. He argues that the effort smacked of a cartel and that the main problem with US chipmakers in the past was their management of manufacturing.

Rodgers claims that US manufacturers have now so improved yields and quality that they have actually held their own against the Japanese in recent years when the effects of the slumping US dollar are taken into account. That sets the stage for future competition based on innovation and new technologies, areas where, he proclaims, "the Japanese are well aware that we will blow them away."
Not everyone agrees. "Let me tell you, we haven't caught up," says Charles Ferguson, a postdoctoral research associate at the Massachusetts Institute of Technology and author of an August 1989 report on the DRAM industry. Ferguson says that without a US Memories, Americans never will catch up. Start-up costs are so staggering, no company could take on the effort alone. At the same time, prices could tumble, destroying profits. And the government is offering little support in developing a comprehensive national strategy - a shortcoming also noted in a report last November by the National Advisory Committee on Semiconductors.

Even if a company could get established, the odds against success are nearly overwhelming. Ferguson notes that Japan is not only ahead of the United States in facility design, but its worker are much better trained.

US Memories mitigated some of these factors, Ferguson says. He believes the decision by many companies not to back the venture is "extremely shortsighted", and adds, "I think they're going to pay dearly for it".

Andrew Procassini, president of the Semiconductor Industry Association, agrees. He admits the venture might have cost members profits for several years. But he argues that it offered the benefit of supporting the entire semiconductor industry's infrastructure.

Robert Buder

\section{Cash and teamwork the answer if US to catch up}

\section{Tokyo}

CoMmenting on the collapse of US Memories, a Japanese expert on the semiconductor industry says that US companies will have to "step on the gas" and "forget about profits" if they want to catch up with Japan.

Hajime Karatsu of Tokai University, a former managing director of Matsushita Communication Industrial Co., is a wellknown and outspoken critic of the US semiconductor industry. His opinions appear to agree both with those of Rodgers (see above) concerning the need for improved production practices, and with supporters of US Memories who argue for massive, long-term investment.

Karatsu says he is "disappointed" that consortia such as US Memories are failing but that it is "quite natural" because even in Japan several consortia have shown poor results. He says that one of the problems is that movements in Washington to catch up with Japan are often "biased and political" and guided by people with little practical knowledge of semiconductor production.

Karatsu was invited by the US Department of Defense to point out differences between the US and Japanese industries.
He believes that much of what he said then still applies today. One thing that is needed, he says, is for US industry to learn how to fight against errors, such as the supply of substandard materials and the breakdown of machines. To overcome these errors, all employees from the shop floor to management must learn to work "hand in hand". These conditions prevail in Japan and can be found in the factories of US semiconductor manufacturers in Japan, such as Texas Instruments. But in the United States "individualism" is a handicap in the "war against errors".

Karatsu says he has visited Austin, Texas, many times and has been awarded honorary citizenship for his support of Sematech. But he says US engineers at Sematech want to be independent and tend not to exchange information with each other. If Sematech is to succeed, they will have to learn to share.

The other major problem for the United States lies at the corporate level. US companies will have to invest "much more money" and neglect short-term profits. If not, the distance from Japanese companies will get "further and further", Karatsu says. David Swinbanks 